\title{
ROV-SCUBA integrated survey of the Montecristo Island Nature Reserve (Tuscan Archipelago National Park, Mediterranean Sea)
}

Lorenzo Angeletti and Alessandro Ceregato

Istituto di Scienze Marine (ISMAR) - Consiglio Nazionale delle Ricerche (CNR), Bologna, Italy

Michele Ghirelli

Robomar S.a.s. and Co., Roma, Italy

Barbara Gualandi

CNR - Area della Ricerca, Bologna, Italy

Enver Lipparini

Instituto di Scienze Marine (ISMAR) - Consiglio Nazionale della Ricerche (CNR), Bologna, Italy

Danilo Malatesta

Robomar S.a.s. and Co., Roma, Italy

Antonio Sperotti

Centro Sub Corsaro, Procchio, Marciana Marina, Livorno, Italy

Marco Taviani

Instituto di Scienze Marine (ISMAR) - Consiglio Nazionale della Ricerche (CNR), Bologna, Italy

\section{Abstract}

A remotely operated vehicle (ROV) survey aimed at exploring the waters around Montecristo Island, a nature reserve in the Tuscan Archipelago (Tyrrhenian Sea), was carried out in summer 2008 down to a maximum depth of ca. $160 \mathrm{~m}$. The main target of this exploration was checking the potential occurrence of deepwater scleractinian corals. Whilst the ROV transects did not document any deepwater corals, they did reveal that the coarse detrital bottom of the Montecristo granitic edifice between 110-160m was dominated by a crinoid facies made of Leptometra phalangium (Müller, 1841) with a density of up to 15 individuals per $\mathrm{m}^{2}$.

Keywords: remotely operated vehicle (ROV), Leptometra phalangium, crinoids, Montecristo Island, Tuscan Archipelago, Thyrrenian Sea, SCUBA

\section{Introduction}

The small island of Montecristo $\left(10.39 \mathrm{~km}^{2}\right)$ is located in the eastern Tyrrhenian Sea at $42^{\circ} 19.9^{\prime}$ lat. $\mathrm{N}, 10^{\circ} 18.5^{\prime}$ long. $\mathrm{E}$ (Fig 1). Montecristo is sub-circular in shape and reaches a maximum height of $645 \mathrm{~m}$ above sea-level, with an almost constant slope of $25^{\circ}$. The island is located near the southern terminus of the shallow Tuscan platform (water depths less than $200 \mathrm{~m}$ ), and at the north end of a highly elongated and pronounced set of north-south trending ridges and basins.

Geologically, the island has granitic rocks, subaerial expressions of a larger plutonic intrusion belonging to the Tuscan Magmatic Province (Sartori, 1989; Innocenti et al., 1997). Several buried granitoid intrusions, comparable in size to the Montecristo and Giglio bodies, have been interpreted on the basis of seismic reflection studies occurring within the ridges south of Montecristo (Zitellini et al., 1986).

The landscape is characterised by huge granitic cliffs that descend steeply to the sea, with little vegetation and some valleys carved by the ancient action of small seasonal streams. Montecristo is part of the Tuscan Archipelago National Park, Integral Nature Reserve, established by Ministerial Decree of 4 March 1971 and declared a biogenetic nature reserve by the Council of Europe since 1988; it has the additional status of being a Special Protection Area (SPA, Directive 79/409/EEC).

As such, Montecristo and adjacent waters up to $1 \mathrm{~km}$ offshore (including the small Scoglio d'Affrica or Formica di Montecristo) are under strict protection by the State Forestry Corps and the Coast Guard. Recreational fishing, bathing and diving are forbidden, as is overnight mooring in the harbour and circumnavigating. Berthing and landing are allowed only with permission of the Territorial Office for Biodiversity of the 


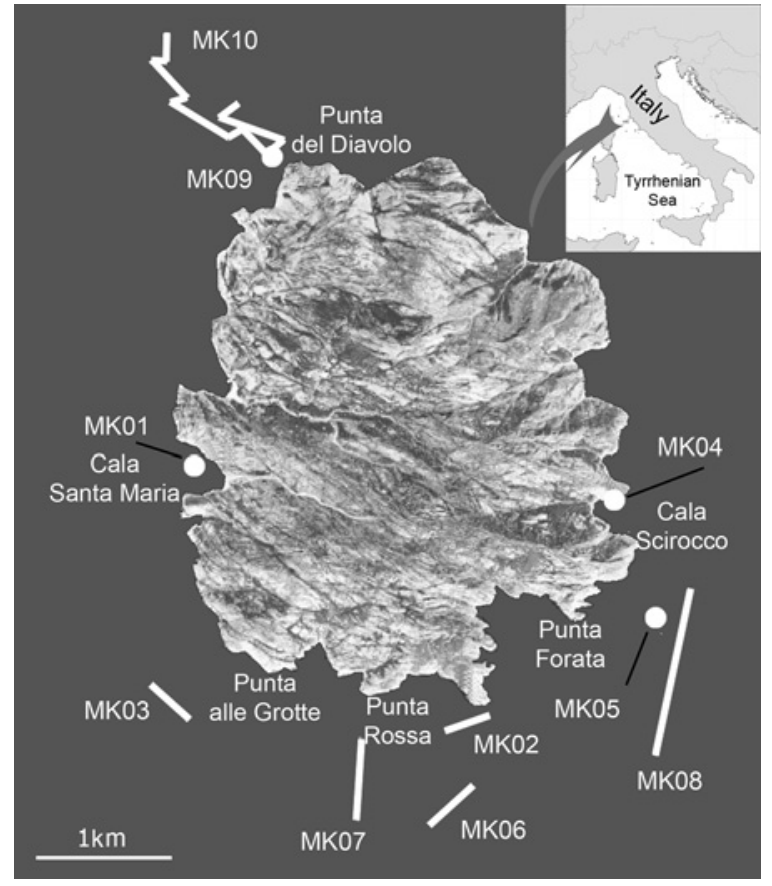

Fig 1: Location map of Montecristo Island (Tuscan Archipelago) showing the routes of ROV (MKO3, MKO7, MKO8 and MK10) and video camera surveys (MKO2 and MK06) carried out in summer 2008, and the dots showing SCUBA dives (MKO1, MKO4, MKO5 and MKO9)

State Forestry Corps of Follonica under specific conditions, and scientific activity is also regulated.

Only a few scientific studies have specifically investigated the marine benthic habitats of Montecristo, and all these were limited to shallow water (e.g., Argano and Pesce, 1976; Cottarelli and Venanzetti, 1989; Pavan, 1989; Papi et al., 1992; Balsamo et al., 1994). The geographic location of the island, transparent waters and steep underwater topography sloping to $>150 \mathrm{~m}$ suggest that the Montecristo submerged edifice might, in principle, sustain deepwater coral communities.

Elsewhere in the Mediterranean Sea, live deepwater branching scleractinian 'white corals' (Madrepora oculata, Linnaeus) have been recently found living in the central Adriatic (Županović and Jardas, 1989), in the south Adriatic off Bari in some canyons of the western basin (Catalan-Provençal margin) (Freiwald et al., 2009) and in the Tigullio Gulf (Tunesi and Diviacco, 1997) at relatively shallow depths (about $100 \mathrm{~m})$. Meanwhile, live 'yellow coral' Dendrophyllia cornigera (Lamarck) is often found between $80-120 \mathrm{~m}$ depth in the Mediterranean Sea (Pérès and Picard, 1964). Such depth ranges are within Montecristo's bathymetric setting and therefore deepwater coral may potentially occur here.

At present, deepwater coral communities are attracting increasing attention by marine scientists as biodiversity hotspots and reliable archives of

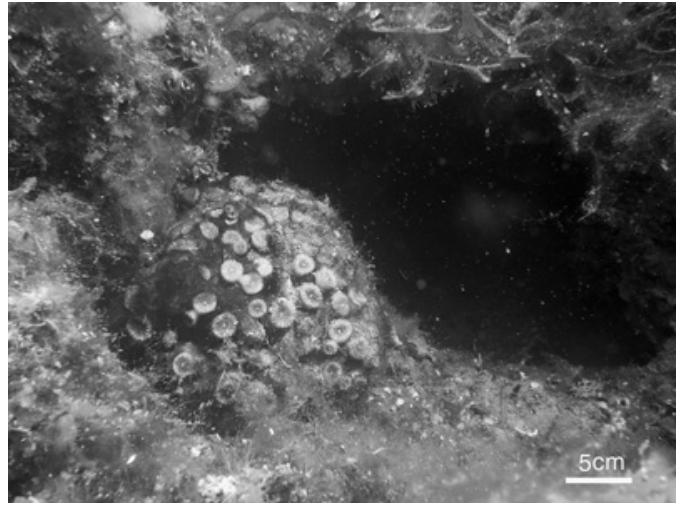

Fig 2: Colony of the scleractinian Cladocora caespitosa at $11 \mathrm{~m}$ depth at Punta Forata (MK05), between Punta Corfù and Cala Rossa (unsuitable for geochemical study because of its small size)

climatic information. In fact, deepwater corals, such as Madrepora, Lophelia and Desmophyllum, and shallow-water corals, such as Cladocora caespitose, could be used for high-resolution climatic reconstructions through the study of geochemical signals encoded in their growth increments (Peirano et al., 2004; Montagna et al., 2008). For this reason, a programme was launched in 2008 that was designed for the non-invasive exploration of the submerged flanks of Montecristo Island to check for the possible presence of corals down to its deepest stretches.

\section{Materials and methods}

Two exploratory surveys were conducted onboard the $\mathrm{m} / \mathrm{b}$ Angélique 1945, using ROV Prometeo Flat Platform 6+ and a Global Vision video camera, operated by Robomar S.a.s. and Co. The survey was complemented with SCUBA diving operations aimed at (a) supporting ROV activity and (b) extending the search for corals to shallower locations. A first survey (12-14 July 2008) was devoted to the calibration of gear and instruments, testing their buoyancy and operational capability. The second phase (25-30 July) resulted in the completion of some ROV transects, underwater camera imaging and SCUBA dives. Meteo-marine conditions during this period were not always optimal and so limited the extent of the operations, especially ROV surveys.

In order to achieve the most comprehensive and representative evaluation of Montecristo's coastline, six stations at different geographic exposures were investigated (Fig 1). Four ROV transects (MK03, MK07, MK08 and MK10) and two video camera surveys (MK02 and MK06) imaged the sea-bottom from $47 \mathrm{~m}$ to $169 \mathrm{~m}$ depth.

The survey was complemented with SCUBA diving exploration down to a maximum depth of 44m (MK01, MK04, MK05 and MK09), aimed at 

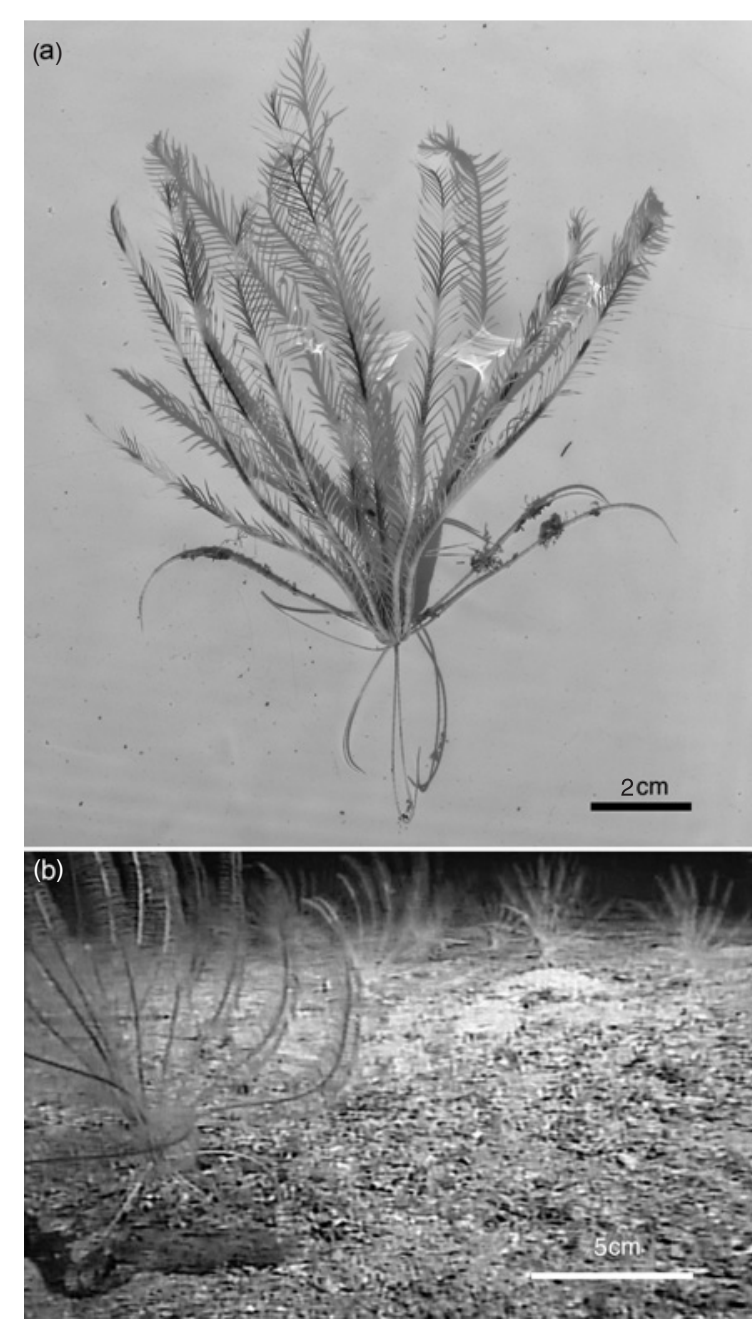

Fig 3: Leptometra phalangium: (a) living individual collected in the Adriatic sea (41.62097 $\mathrm{N}$ $16.94475^{\circ} \mathrm{E}, 155 \mathrm{~m}$ depth: st. ARCADIA-83, RV Urania, 26 March 2010) and (b) crinoid field off Montecristo imaged by ROV Prometeo at ca. 160m depth (MKO7)

searching well developed colonies of Cladocora caespitosa suitable for paleoclimate-oriented ongoing geochemical research (Fig 2).

\section{Results}

The best ROV transects were obtained at the two sites, Punta Rossa and Punta del Diavolo, down to a maximum depth of about $160 \mathrm{~m}$ (Fig 1). Although the survey did not reveal any evidence of deepwater coral, it provided first-hand information on previously uncharted deep-sea habitats. In fact, the ROV exploration identified and documented for the first time the presence of extensive crinoid facies all around the island, starting from a depth of $110 \mathrm{~m}$ (Fig 3).

ROV transects at Punta Rossa, Punta Forata and Punta del Diavolo imaged a sea-bottom characterised by the absolute dominance of crinoids with an estimated density as high as 15 individuals per $\mathrm{m}^{2}$. Spot checks conducted using the video camera at other locations around Montecristo further confirmed the ubiquity of crinoid facies, which is, therefore, the key assemblage inhabiting the coarse circalittoral detrital bottoms surrounding Montecristo. During the diurnal surveys, almost all the crinoids were actively feeding.

Since the terms of the permit did not allow sampling of the seabed, the crinoids were only identified from the video record as Leptometra phalangium (Müller, 1841). This is a common echinoderm widely distributed in the Mediterranean Sea (Pérès and Picard, 1964; Bianchi et al., 1993; Tunesi and Diviacco, 1997; Colloca et al., 2004; Pellegrini and Sartor, 2005; De Ranieri et al., 2006; Mifsud et al., 2009), where it lives with the similar Leptometra celtica (M'Andrew and Barrett, 1858) of the eastern Atlantic continental shelf edges (Lavaleye et al., 2002).

In the Mediterranean, Leptometra phalangium is a well known component of circalittoral communities of the edge shelf, the 'Detritique du Large' (offshore detrital biocoenosis) of the Pérès and Picard (1964) bionomic scheme, and is widespread in the Tyrrhenian Sea, including other sectors of the Tuscan Archipelago. Sea-lily gardens are typical of the most productive steep detrital slopes, sometimes replacing Funiculina quadrangularis (Pallas) in bottoms subjected to trawling (Tunesi and Diviacco, 1997; Colloca et al., 2004).

\section{Acknowledgements}

This research was partly funded by the FP VI Integrated Project EU Hermes programme (GOCECT-2005-511234-1). The authors thank two anonymous referees for their critical review of the manuscript. This is ISMAR-Bologna scientific contribution no. 1654 .

\section{References}

Argano R and Pesce GL. (1976). Isopodi dell'Isola di Montecristo (Crustacea). In: Baccetti B. (ed.). Il popolamento animale e vegetale dell'Arcipelago Toscano. Lavori Società Italiana di Biogeografia 5: 371-383.

Balsamo M, Fregni E and Tongiorgi P. (1994). Marine and freshwater Gastrotricha from the Island of Montecristo (Tuscan Archipelago, Italy) with the description of new species. Italian Journal of Zoology 61: 217-227.

Bianchi CN, Ceppodomo I, Niccolai I, Aliani S, De Ranieri S, Abbiati M, Dell'Amico F and Morri C. (1993). Benthos dei mari toscani. II: Isola d'Elba - Montecristo (crociera ENEA 1986). In: Ferretti O, Immordino F and Damiani V. (eds.). Arcipelago Toscano: Studio Oceanografico, Sedimentologico, Geochimico e Biologico. Roma: ENEA, 291-316.

Colloca F, Carpentieri P, Balestri E and Ardizzone GD. (2004). A critical habitat for Mediterranean fish resources: shelf-break areas with Leptometra phalangium (Echinodermata: Crinoidea). Marine Biology 145: 1129-1142. 
Cottarelli V and Venanzetti F. (1989). Ricerche zoologiche della nave oceanografica 'Minerva' (C.N.R.) sulle isole circumsarde. II. Cylindropsyllidae del meiobenthos di Montecristo e delle isole circumsarde (Crustacea, Copepoda, Harpacticoida). Annali del Museo Civico di Storia Naturale 'G. Doria' 87: 183-235.

De Ranieri S, Reale B, Ligas A, Sartor P, Viva C, Bertolini D and Belcari P. (2006). Caratterizzazione della fauna associata alla facies a Leptometra phalangium (J. Müller, 1841) (Echinodermata; crinoidea) nel mar Tirreno Settentrionale. In: Domenici V and Lenzi A. (eds.). Codice Armonico. Primo Congresso di Scienze Naturali Della Regione Toscana. Roma: Zadigroma, 32-36.

Freiwald A, Beuck L, Rüggeberg A, Taviani M, Hebbeln D and R/V Meteor Cruise M70-1 Participants. (2009). The white coral community in the Central Mediterranean Sea revealed by ROV surveys. Oceanography 22: 58-74.

Innocenti F, Westerman DS, Rocchi S and Tonarini S. (1997). The Montecristo monzogranite (Northern Tyrrhenian Sea, Italy): a collisional pluton in an extensional setting. Geological Journal 32: 131-151.

Lavaleye MSS, Duineveld GCA, Berghuis EM, Kok A and Witbaard R. (2002). A comparison between the megafauna communities on the N.W. Iberian and Celtic continental margins, effects of coastal upwelling? Progress in Oceanography 52: 459-476.

Mifsud C, Taviani M and Stöhr S. (2009). Remarks on Echinodermata from the South Central Mediterranean Sea based upon collections made during the MARCOS cruise (10-20 April 2007). Mediterranean Marine Science 10: $63-71$.

Montagna P, Silenzi S, Devoti S, Mazzoli C, McCulloch M, Scicchitano G, Sparaini F and Taviani M. (2008). High resolution natural archives provide new tools for climatic reconstruction and monitoring the Mediterranean Sea. Rendiconti Lincei 19: 121-140.

Papi I, Pardi G, Lenzini S, Benedetti Cecchi L and Cinelli F. (1992). Benthic marine flora in the Tuscan Archipelago. A first contribution: Isles of Capraia, Elba, Formiche di Grosseto, Giglio, Scoglio d'Africa, Montecristo and Giannutri. Plant Biosystems - An International Journal Dealing with all Aspects of Plant Biology 126: 549-593.

Pavan M. (1989). Isola di Montecristo. Riserva naturale. Collana Verde, Ministero Agricoltura e Foreste 77: 1-125.

Peirano A, Morri C, Bianchi CN, Aguirre J, Antonioli F, Calzetta G, Carobene L and Mastronuzzi G. (2004). The Mediterranean coral Cladocora caespitosa: a proxy for past climate fluctuations? Global and Planetary Change 40: 195-200.

Pellegrini D and Sartor P. (1989). Distribuzione spaziotemporale degli Echinodermi dei fondi molli del Mar Tirreno Settentrionale nel triennio 1985-87. Nova Thalassia 10: 603-605 (suppl. 1).

Pérès JM and Picard J. (1964). Nouveau manuel de bionomie benthique de la mer Méditerranée. Recueil des Travaux de la Station Marine d'Endoume 31: 1-137.

Sartori R. (1989). Evoluzione neogenico-recente del bacino tirrenico e suoi rapporti con la geologia delle aree circostanti. Giornale di Geologia 51: 1-39.

Tunesi L and Diviacco G. (1997). Observations by submersible on the bottoms off shore Portofino Promontory (Ligurian Sea). In: Piccazzo M. (ed.). Atti del 12 Congresso dell'Associazione Italiana di Oceanologia e Limnologia (Isola di Vulcano). 18-21 Settembre 1996, 1 - Genova, 61-74.

Zitellini N, Trincardi F, Marani M and Fabbri A. (1986). Neogene tectonics of the Northern Tyrrhenian Sea. Giornale di Geologia 48: 25-40.

Županović Š and Jardas I. (1989). Jabučka Kotlina. Fauna I Flora Jadrana 4: 1-415.

\section{Subsea Control and Data Acouisition 2010}

Future Technology, Availability and Through Life Changes

Proceedings of the International Conference held in Newcastle, UK, 2-3 June 2010

ISBN 0906940524

ISBN-13 9780906940525

Hardback edition 2010

Published by SUT

176 pages plus CD-ROM

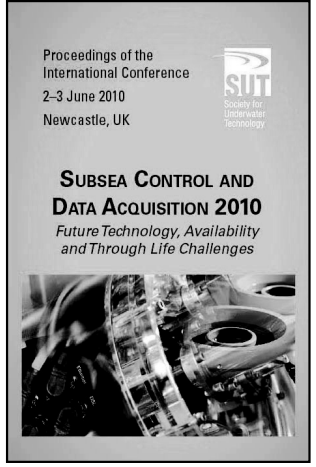

Price: $\mathbf{f 9 5}$

*10\% discount for SUT members and booksellers

This long established international conference dealing exclusively with underwater instrumentation, control and communication technology for subsea oil and gas production has been structured to cover relevant experience and new thinking in subsea developments. Providing a unique forum for the supplier and operator of subsea technology to exchange views and experiences, its aim is to bring together the many diverse disciplines engaged internationally in this technology. Experience gained and current challenges, as well as new advances in technology, will be the main topics to meet the future challenges. Equalimporta Equalimportan deepwater problems and long distance offsets. These proceedings will feature contributions from professionals giving experience gained and new challenges to overcome and is therefore of interest to all in subsea engineering.

For more information or to purchase a copy, contact SUT Head Office 80 Coleman Street London EC2R 5BJ UK t 02073822601 f 02073822684 e info@ sut.org 